\title{
The Evidence Written in Stone: An Evaluation of the Relationship (or Not) of Syrian and Georgian Ecclesiastical Architecture
}

\author{
Giorgi Chubinashvili and the Cult of Georgian Exceptionalism
}

C'est précisément au début de la période de féodalité que la culture et l'art géorgiens acquirent définitivement leur propre caractère national nettement prononcé. ${ }^{1}$

Anyone seeking to become acquainted with the history of Georgian Architecture will soon become aware of the fact that the field is fraught with methodological problems and has been largely static since the death of Giorgi Chubinashvili in 1973. Chubinashvili was the dominant figure in the field throughout the Soviet era and the subject is still controlled by his students, who have failed to significantly move the discipline forward in the forty-five years since his death. Whilst Chubinashvili may be credited as the founding father of the modern disciplines of art and architectural history in Georgia and is notable for his extensive publications, in common with a number of Soviet scholars his output is now widely viewed as being of variable quality. Particular instances where recent research has proved Chubinashvili's suppositions to be wrong will be discussed later in this chapter but here it is important to highlight from the outset the fact that his limitations are rooted in three particular issues.

The first is that he was handicapped by working on a largely ecclesiastical architectural tradition in a time and place where theological knowledge was unavailable and actively forbidden as an area of research, meaning that he could only study the monuments in a schematic manner that divorced form from function; this facilitated the development of a typology of ecclesiastical architecture that did not question the developing ritual needs of the

1 p. 3, Beridze, Vaktang, 'L'architecture religieuse georgienne des Ive-VIIe siecles', Kartuli khelovnebisadmi misdzghnili II saertashoriso simpoziumi, Institut Tschubinaschvili d' histoire de l' art georgien, Metsniereba; Tbilisi, 1977.

(C) EMMA LOOSLEY LEEMING, 2018 | DOI:10.1163/9789004375314_007

This is an open access chapter distributed under the terms of the prevailing CC-BY-NC License at the time of publication. 
faithful and relied entirely on a few dated inscriptions along with a visual evaluation of decorative elements as the mechanism by which a fixed chronology was established. The second impediment was the prevailing narrative of Georgian exceptionalism - succinctly summarised in the quotation by Beridze above. Even in the Soviet era Georgian historical sources abound in examples of work where the national identity of Georgia and the Georgian 'national character' is given a disproportionate emphasis and there is a failure to contextualise material into a wider Transcaucasian framework. In this instance this attitude is most clearly expressed in a tendency to mention Armenian monuments in passing or not at all, meaning that as observed in the introduction to this volume, very little work has yet been undertaken in order to understand events in Georgia in tandem with what was happening in Armenia, Caucasian Albania and further afield. The final difficulty was entirely beyond the physical or ideological control of Chubinashvili and his contemporaries. This limitation was that aside from areas such as Armenia and Azerbaijan that were also within the Soviet Union, it was impossible for Georgian scholars to travel to other countries. Therefore they could only write about monuments in places such as Asia Minor and Syria based on the literature on these sites they were able to access. In the era of the internet it is very easy to forget how academic research has been revolutionised in less than two decades by the advent of the world wide web. Not only are we able to locate scholarly materials more easily, but we can also access photographs and maps that enable us to travel virtually across the globe in a manner that simply wasn't possible until the advent of the digital age. Knowing where to begin to search for information is half the battle for scholars and unable to visit the sites in question, working from a few floorplans and largely outdated texts, it is unsurprising that Chubinashvili often failed to interpret monuments in Syria and Asia Minor correctly. On the other hand, this practice of using limited and outdated sources is still widespread and considered acceptable academic practice in many areas of contemporary Georgian academia today where there is a general lack of robustly peer-reviewed journals and a significant portion of the current 'academic' output is self-funded without any effective quality control. In part this situation is a symptom of the post-Soviet collapse of academia discussed in chapter one, but it is also indicative of a small society that has become more inward-looking as education in foreign languages has declined since 1991.

Despite this there are naturally a number of exceptions to prevailing trends and, in archaeological research at least, Chubinashvili's typology is being successfully challenged by the results of recent excavations in the Kakheti region of eastern Georgia. Here the arguments are supported by scientific data such 
as C14 dating, stratified numismatic finds and a clear ceramic typology ${ }^{2}$ that is now being cross-referenced with $\mathrm{C} 14$ results. A recent paper sums up the state of Georgian research in the field in the following terms:

The mentioned above rather strange versions hastily elaborated by the representatives of the Georgian art history school in relation to the given problem in the 20-s of the last century, have not experienced substantial evolution for decades. For example, even today in the works of these researchers we can find the propositions supposing that allegedly, unlike the whole early Byzantine world and countries within its cultural circle, the Iberian authorities, during more than a century after recognition Christianity as the state religion, have been building exceptionally miniature churches of almost any design, based on the oral descriptions of the missionaries about the temples of leading Christian countries (due to inadequate perception of liturgical processes performed there) ...

... Even recently, the mentioned above part of the Georgian art historians have named the impeding reason for revising this almost dogmatic, not documentarily confirmed opinion, stating that in order to revise the described proposition, they practically have not had tangible materials at hand-i.e., could not find above-ground remaining samples of large churches, built in the IV or even last quarter of the V centuries in East Georgia with objective dating signs, constructed in accordance with the accepted canonical planning, recognized by the early Christian foreign world; such monuments were not revealed even 15 years ago through archeological methods. ${ }^{3}$

So if we accept that the comparisons of Syrian and Georgian architecture made by Georgian scholars are often based on flawed assumptions and understand that on the other side of the equation only passing references are made to Transcaucasian monuments in works examining Syrian ecclesiastical architecture, where should we begin in formulating a comparative study of Syrian and Georgian ecclesiastical architecture in late antiquity?

2 Bakhtadze, Nodar, Ceramics in Medieval Georgia, Georgian National Museum; Tbilisi, 2013.

3 Bakthtadze, Nodar, 'The Oldest Basilicas Revealed in Nekresi Former City and Hypotheses on the Architectural Design of the First Georgian Christian Churches', Jena, 2017 (forthcoming). 


\section{Syria and Mesopotamia: A Story of Two Distinct Architectural Traditions}

As discussed above in chapter one, the country that we call Syria today actually straddles the two older territories of Syria and Mesopotamia. It also encompasses very different geographical and geological features meaning that building styles and techniques vary significantly between the east and west of the country. In particular, as discussed in chapter two, the plentiful supply of stone (in particular limestone and basalt) in the west of the country is not replicated in the east where rough fieldstone and rubble construction or adobe buildings are the norm. This is highlighted here because although there has been a concentration on studying the elegant, well-preserved stone edifices in the west, in particular the dense concentration of villages on the Syrian limestone massif between Aleppo and Antakya, straddling the Syrian-Turkish border ${ }^{4}$ there has been less work undertaken in the east of the country where there is less extant archaeology above the surface of the landscape given the more fragile nature of the building technique and the fact that the sandy soil has been more likely to cover abandoned buildings than in the west, where the soil is denser and has largely remained under cultivation as olive and fruit orchards or used for pasturing animals.

As the eastern part of Syria is largely a desert landscape, the only significant occupied zone has been the fertile strip along the line of the River Euphrates and its tributaries, particularly the River Khabur that joins the Euphrates just south of the modern town of Al Busayrah. Although the archaeological significance of this region has long been recognised with the spectacular Bronze Age city of Mari and the exceptional preservation of the Roman era town of Dura Europos ${ }^{5}$ located on the west bank of the Euphrates in the far east of the country, as with other parts of the country, archaeological exploration of the region was only expanding to other, less exceptional sites in the decades before the outbreak of war in 2011.

Both this relative lack of archaeological research as well as the later influx of foreign researchers, were due to a variety of complex socio-political and economic problems specific to the northeastern part of the country. In the first

4 And here the author must also plead guilty to a concentration on this region in the past, for example in her doctoral research published as Loosley, Emma, The Architecture and Liturgy of the Bema in Fourth to Sixth-Century Syrian Churches, UsE K, Patrimoine Syriaque vol. 2; Kaslik, Lebanon, 2003 (re-issued in a second edition by Brill, 2012).

5 For more on Dura Europos see chapter two. 
instance the far northeast region in and around the city of Hassakeh was inhabited largely by Kurds and Christians, the majority of whom were members of the Syrian Orthodox Church or of the Church of the East. Some of these groups had been resident in the region for many generations, but a large number had moved there fleeing twentieth century persecutions and this movement continued throughout the twentieth century as Christians fled discrimination in Turkey and Kurds fled violence in both Turkey and Iraq. The ongoing conflict in Iraq had also led to the creation of refugee camps in the area and the region was viewed by distrust by the government due to the presence of a number of Christian and Kurdish political movements being active in the province. ${ }^{6}$ Further south, towards the city of Deir ez Zor the local population was dominated by powerful Sunni Arab tribes, who also chafed under Ba'athist rule and were viewed with suspicion by Damascus.

Given that Deir ez Zor was the centre of the Syrian oil industry, the government sought to keep a tight lid on any possible disruption in the area and part of this process involved limiting the access of foreigners to the wider region, unless they were in the employ of an oil company or part of an organised tour visiting the most famous archaeological sites along the Euphrates. An exception to this was made from the 1980 os onwards as a series of dam construction projects led to teams of archaeologists being invited to undertake salvage expeditions ahead of construction work in anticipation of the rising water levels. However, perhaps unsurprisingly given the wealth of prehistoric remains in the region, the salvage effort overwhelmingly concentrated on the earliest periods of occupation represented by the string of tells stretching across the landscape. The sole project to prioritise a later period, specifically the late antique and medieval evolution of a settlement, was the American Mission to Tell Tuneinir led by Michael and Neathery Fuller of the St. Louis Community College, Missouri. Unfortunately the campaign has never been fully published, but a summary of the findings of the expedition including maps, pictures and C14 dating results have been made available online. ${ }^{7}$

Several years before the outbreak of the Syrian civil war in 2011 a new dam was planned for the Khanuqa Gap on the Euphrates in order to create a second large reservoir east of the Assad Lake, which was formed by the building of the Euphrates Dam at Tabqa, west of Raqqa. The Directorate General of Antiquities and Museums (DGAM) fought this development on the grounds that it

6 Pers. comm. with various informants who shall remain unnamed for safety considerations given the conflict situation in both Syria and Iraq at the time of writing.

7 For the project archive see https://users.stlcc.edu/mfuller/tuneinir/ (Accessed 31.03.2017). 
risked irrevocable harm to an area of outstanding archaeological significance, but eventually were overruled by a ruling by the Supreme Constitutional Court of Syria and left with no options but to mobilise archaeologists to the region to salvage as much information as possible before it was destroyed by the rising water levels. ${ }^{8}$

This mobilisation of archaeologists into the area immediately upstream of Deir ez Zor complimented the long-running French Misson to Halabiyeh/ Zenobia that had worked on the Classical and Late Antique city, by facilitating a Syrian exploration of the Byzantine era site at Kasra ${ }^{9}$ and a British-Syrian project at the Byzantine/early Islamic fortress at Zalabiyeh ${ }^{10}$ however, this was only the beginning of the exploration of this period in this particular province in Syria and the outbreak of the civil war in 2011 has meant that only a small proportion of the potential data was retrieved from the region before excavations were curtailed by the hostilities. Despite these significant limitations, what can be discerned from the Tell Tuneinir material is that stylistically the ecclesiastical material of Syrian Mesopotamia (the part of contemporary Syria that lies on the east bank of the Euphrates) is far closer to Sassanian forms of artistic expression than it is to the clearly Romano-Byzantine idioms familiar in the west of the country. The curving foliate and arabesque motifs that are found in conjunction with the imagery of the cross in Tell Tuneinir find their parallel in forms found across the wider region to the east of the Euphrates and appear as far afield as Kerala in southern India. The sinuous foliate reliefs and capitals known from Sassanian decoration were a formative influence on the art of the Church of the East ${ }^{11}$ and also found favour with the Syrian Orthodox who settled within the region.

Neither tradition of decoration in Syria particularly favoured the use of figural, or even animal, motifs with the notable exception of mosaic pavements where a variety of non-religious scenes have been discovered..$^{12}$ There was also a

8 Pers. comm. Dr. Michel al Maqdissi of the DGAM in negotiations to begin excavations at Zalabiyeh, December 2009.

Abdullah, Yaarob, 'The Works of the Syrian Mission in the Byzantine City (Tell Al Kasra) in Five Seasons (2006-2010)', Res Antiquitatis 2 (2011), pp. 269-285.

10 Loosley, E., 'The Citadel of Zalabiyeh on the Euphrates: Placing the site in its historical context and a summary of the first archaeological field season (2010), Res Antiquitatis 2 (2011), pp. 259-268, Loosley, E. \& Bryant, J., 'Zalabiyeh on the Euphrates: The Historical Evidence and the 2010 Archaeological Discoveries', Res Antiquitatis 5 (2014).

11 As mentioned above, this is the correct term today for the group formerly pejoratively referred to as the Nestorian Church. 
relative lack of epigraphic data included in the decoration of these early ecclesiastical monuments in the west, where Syriac inscriptions in stone were quite rare and any data was more likely to have been recorded in Greek, or in the earlier monuments of the first and sceond centuries CE even in Latin. The evidence from Tell Tuneinir provided a great deal more epigraphic data than was generally present in western sites and all of it was in the Syriac estrangelo script, again suggesting a very different tradition of adorning churches and monasteries in the Mesopotamian region. Therefore when people refer to the 'Syrian Style' of ecclesiastical architecture and the related language of architectonic ornament ${ }^{13}$ they are overwhelmingly referring to the style associated with the stone-built monuments of the west of the country-in particular those of the northwest limestone massif, although a certain amount of attention has also been paid to the buildings still extant from the same period in the south of the country. This style is an elegant Romano-Byzantine adaptation of the Classical repertoire of architectural ornament in which typical elements such as dentillated window mouldings, acanthus capitals and Greek key motifs are found alongside Christian imagery such as the Chi Rho and, overwhelmingly, the equal-armed cross.

With so little known about the traditions further to the east there has been a tendency to suggest one uniform 'Syrian Style' and yet the evidence does not support this-instead it points us towards the existence of a second parallel tradition in Syrian Mesopotamia that was part of the Sassanian world in artis-

that such imagery barely reached double figures. He said that Lassus argued that around 20 such representations had been found on the Syrian limestone massif, another 5 in and around Antioch, 12 from the northeast of Syria and 5 of uncertain provenance. To this Nasrallah added 3 more examples from the Qalamoun region of central Syria and 1 more from Salamiyeh in the northeast. See Nasrallah, Joseph, 'Bas-reliefs chrétiens inconnus de Syrie', Syria 38:1 (1961), pp. 35-53. Although this article is now clearly rather old, it is difficult to evaluate how many more such artefacts were discovered after this article. Certainly there were no newer reliefs on show in national museums (or kept in storage) and, as mentioned in the article, many finds disappeared into private collections - suffice it to say the overall picture has not changed substantially since 1961 and there is no reason to believe that we will find a great deal of figurative art from this period in the future. The sole exception being in the field of floor mosaics, where it is not uncommon to find pastoral or classical scenes in the most well-funded ecclesiastical endowments.

13 See in particular Strube, Christine, Baudekoration im Nordsyrischen Kalksteinmassiv. Band I. Kapitell-, Tür- und Gesimsformen der Kirchen des 4. und 5. Jahrhunderts n. Chr, Philipp von Zabern; Mainz, 1993, Strube, Christine, Baudekoration im Nordsyrischen Kalksteinmassiv. Band II. Kapitell-, Tür- und Gesimsformen des 6. und frühen 7. Jahrhunderts n. Chr. Philipp von Zabern; Mainz, 2002. 
tic terms and which called upon Persian artistic idioms to forge a new and different Christian language. This east Syrian tradition does not draw primarily from the Classical vocabulary that is the foundation of the western Syrian style, but is instead a tradition that mixes Sassanian artistic traditions with the native Semitic style most famously apparent at Palmyra. Once this situation is made clear and these two distinct architectural and artistic currents are separated from each other the relationship with Georgia begins to make more sense. Naturally there was some overlap between the two neighbouring Syrian and Syro-Mesopotamian traditions, notably in places like Palmyra that took elements from both cultures, but in Kartli we see a clear preference for a Sassanian and east Syrian idiom that bears little relation to the Christian architecture of western Syria in late antiquity.

\section{Bolnisi Sioni and the Beginnings of Georgian Christian Architecture}

The first securely dated church still extant in Georgia today is the large basilica at Bolnisi in Kvemo Kartli. The early Georgian inscription on the exterior of the central apse ${ }^{14}$ dates the completion of the construction of the church to the year 493. It states that the project was begun in 478 by Bishop David and that Shah Peroz was ruler at the time that building commenced. ${ }^{15}$ However the inscription fails to refer to the ruler of Persia at the time of the completion of the project or to name the ruler of Kartli, who at the time was the semilegendary Georgian King Vakhtang Gorgasali. Bolnisi Sioni is by no means the first church to have been built in Georgia (although it is the first to bear a foundation inscription) and we will turn to some of the earlier monuments later in this chapter, but is highlighted here because the inscription makes it abundantly clear that in this region at least the Persian Shah was of more significance to the local populace than the Kartvelian monarch in the new capital of Tbilisi.

With this being the case it should then come as no surprise that the decorative scheme of the church is typically Sassanian utilising the same foliate motifs found throughout the Persianate world at this time (Fig. 13). This similarity extends beyond vegetal and geometric patterns into the realm of three dimensional statuary with the inclusion of a bull's head sculpted in an exterior

\footnotetext{
14 The inscription in place today is a replica-the original is now housed in the Shalva Amiranashvili Museum of Fine Art in Tbilisi.

15 p. 61, Chubinashvili, Giorgi N., 'Bolnisskiň sion (k voprosu èvoliutsii bazilichnoŭ formy)', Iz Istorii Srednevekovogo Iskusstva Gruzii, Sovetskiŭ Khudozhnik; Moscow, 199o, pp. 6o-71.
} 


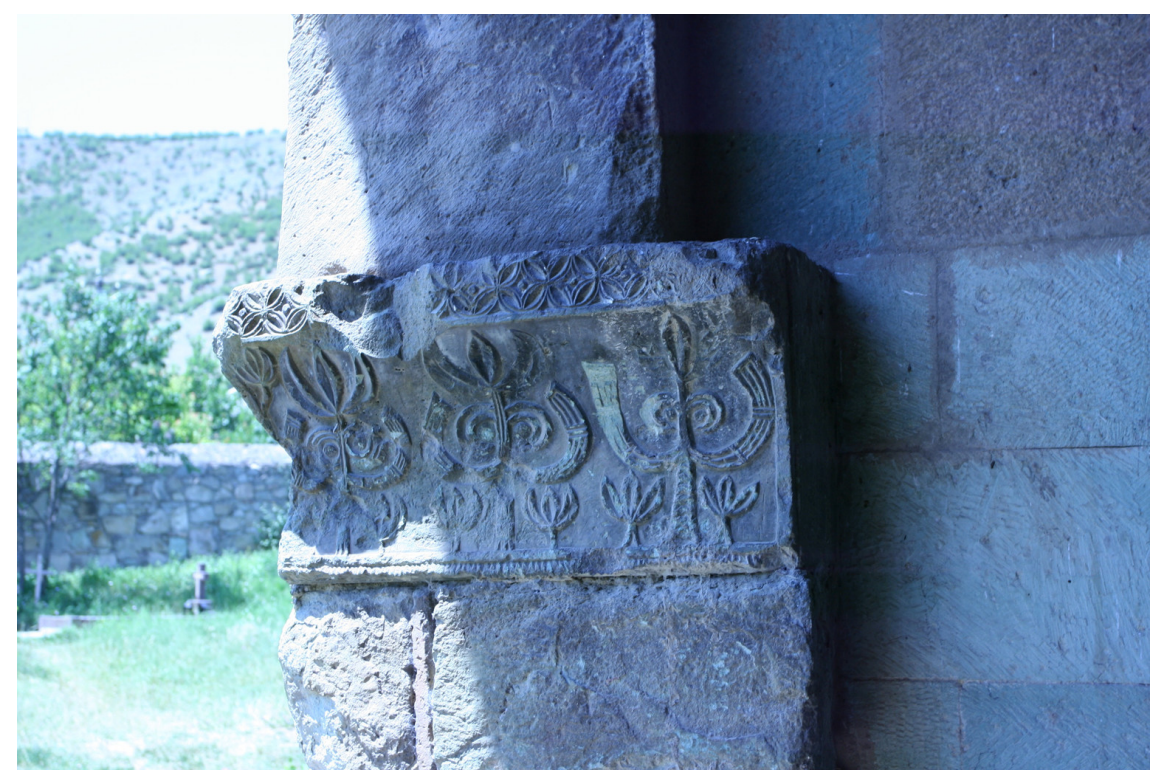

FIGURE 13 Example of Sassanian influenced decoration at Bolnisi Sioni

aisle of the church that is very close in execution to an example from Hajiabad in Fars, Iran, dated to the fourth century. ${ }^{16}$ This conjunction of Persian influenced architectonic decoration and the emphasis on the Shah over the local ruler make it clear that in this region of Kvemo Kartli, which was an area in the marchlands that fell between Armenia and the heart of of Kartvelian territory, the overriding cultural influence came not from Syria, but from the Persian east. However, if we take into account the evidence from Syrian Mesopotamia discussed briefly above, we can see that this style was a constant and unifying element amongst all peoples under Persian suzerainty and its idiom was adapted by people following a variety of religious practices, from the native Persian Zoroastrians to Christians and, later, to the first Muslims who expanded into Persian territory.

This adaptation of Sassanian architectonic idioms should come as no surprise in Kartli, given the widespread influence of Sassanian art, architecture and literary culture throughout the classical era and beyond into the early

16 This head was labelled as a Zebu, but actually looks closer to a bull and was seen by the author in a temporary exhibition at the National Museum of Tehran, Iran in 2006. Ayazi, Souri \& Miri, Sima, Decorative Architectural Stucco from the Parthian and Sassanid eras, National Museum of Iran; Tehran, undated. 


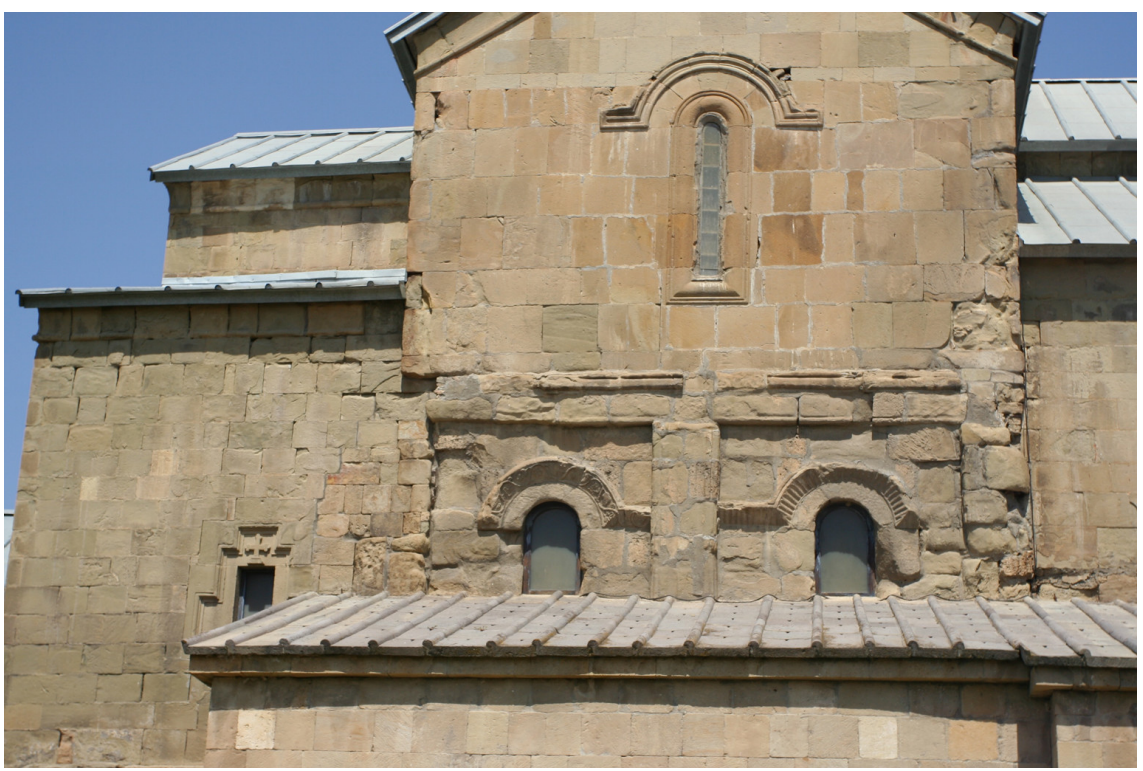

FIGURE 14 South façade of Tsilkani with decorative bands over windows

Christian period. The curling vine scrolls, arabesques and lavishly stylised foliate motifs are most apparent in southern and central regions where the soft rock, in particular the beautiful Bolnisi tuff, was easily dressed as large uniform masonry blocks and was also eminently suitable for carving into capitals, decorated pilasters and lintels and other ornamental elements. Therefore the visual legacy of a Sassanian heritage is prominent throughout the southern marchlands and northwards into Shida Kartli wherever elements of the earliest decorative schema of churches remain extant.

For example at Tsilkani in Shida Kartli a first glance at the church reveals the remnants of the original late antique structure on the south façade of the building. The initial impression is suggestive of a link with Syrian ecclesiastical decoration. The swooping curve of the decorative band that follows the top line of the window arches as a curvilinear motif along the edge of Syrian monuments was a common exterior feature on the limestone massif and here at Tsilkani we seem to be encountering the same form of decoration (Fig. 14). In Syria we can observe this feature particularly at high status fifth century sites such as Qal'at Sem'an (Fig. 15) and Qalb Lozeh, where a decorative band of linear decoration snakes across the building exteriors demonstrating a commitment to the high quality execution of work both inside and out. However, closer examination of these superficial parallels reveals that at Tsilkani there is a T-shaped panel disrupting the flow of the decorative band between the 


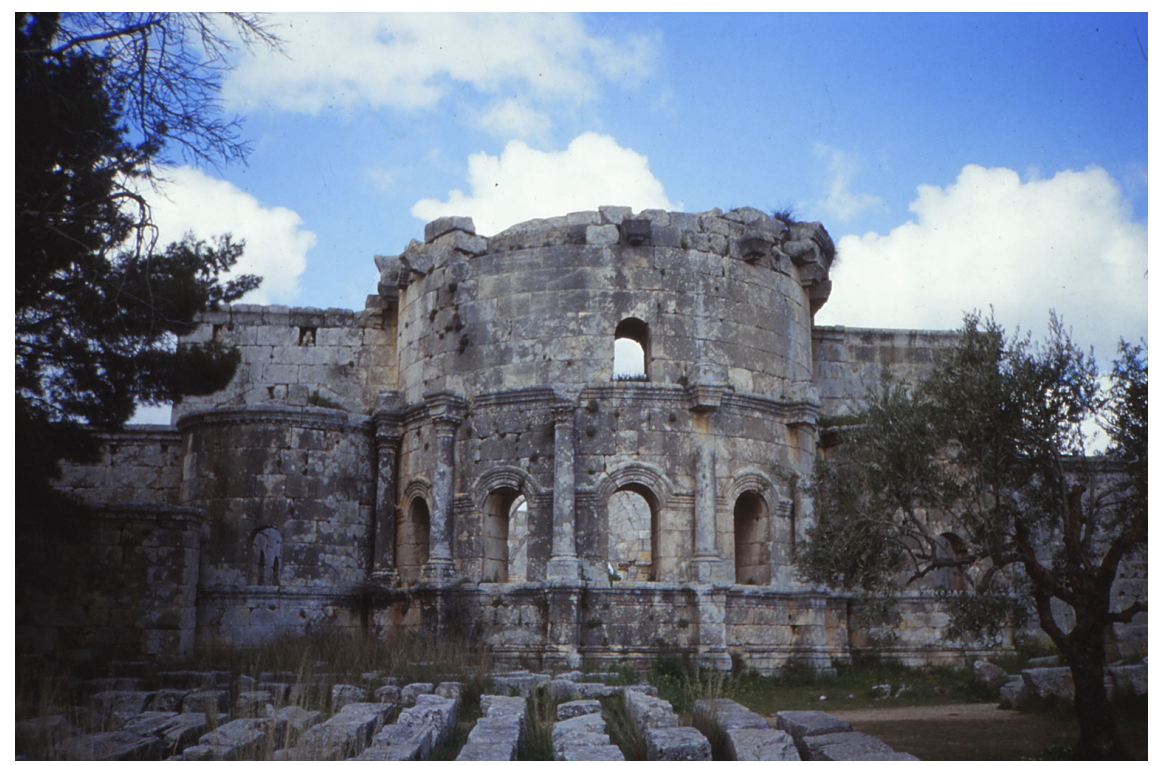

FIGURE 15 Exterior view of the apse at Qal'at Sem'an showing the linking band of decoration around the windows

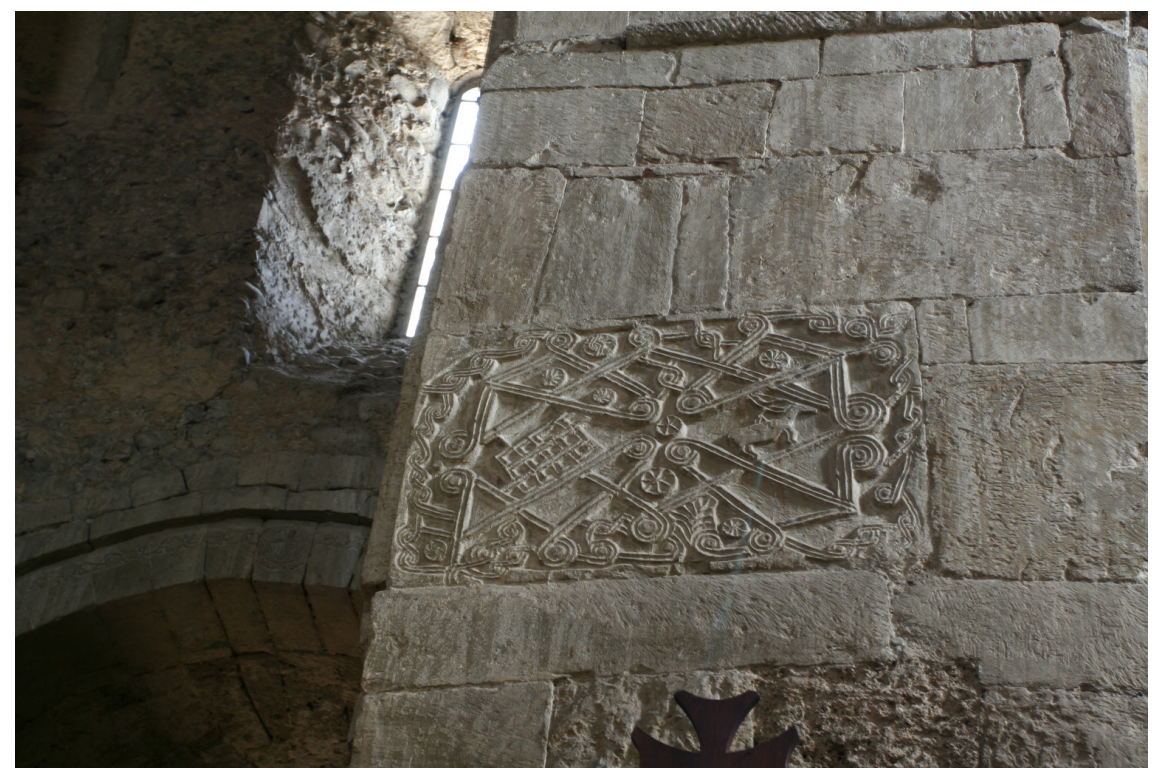

FIGURE 16 Possible spolia inside Tsilkani church 


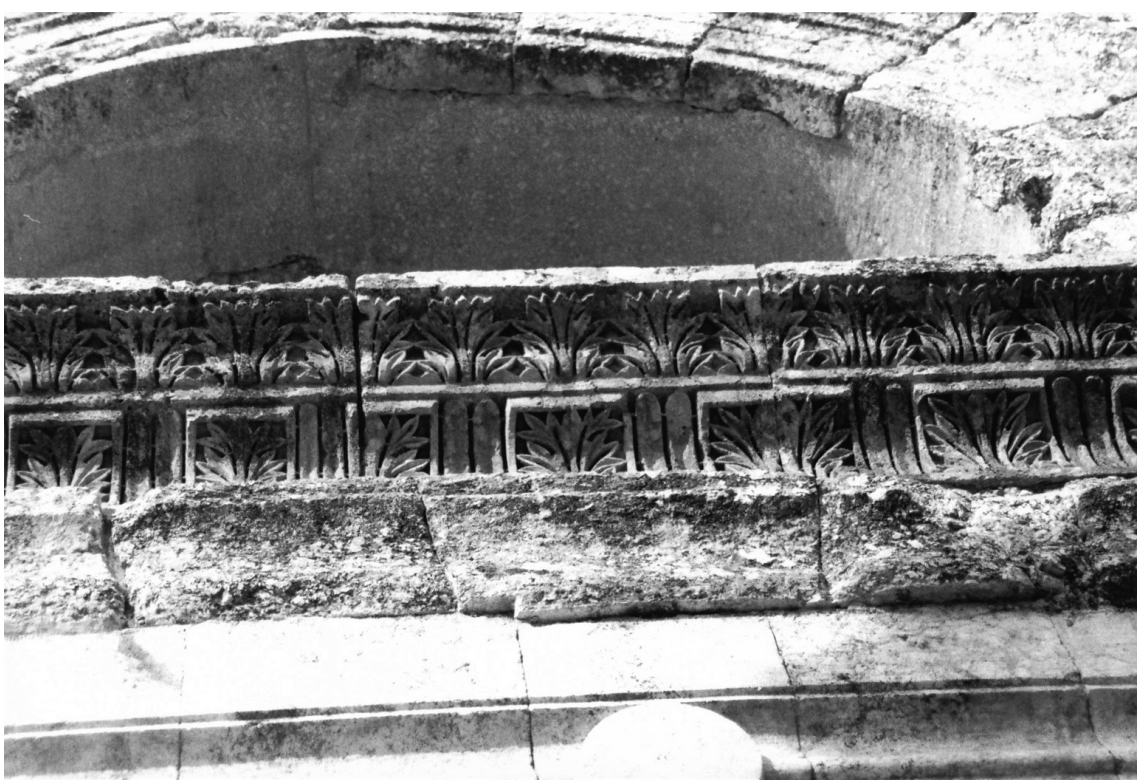

FIGURE 17 Decorative detail from Qal'at Semán

two windows that remain of the earliest building phase-an element unknown in Syrian buildings of the same period. In addition the two windows have different motifs above them; that to the west has a vinescroll pattern, while that further east has a far simpler design of perpendicular lines. On closer analysis it becomes clear that in reality this fragment of the original façade bears little similarity to the horizontal linearity familiar from the Syrian limestone massif. This dissonance between the Syrian and Kartvelian traditions is further apparent in the church interior where spolia from the earlier structure have been incorporated in the fabric of the medieval renovation of the church (Fig. 16). Here again the stylised foliate motifs are more rounded and fluid than the schematized horizontal bands utilised in northwestern Syria. In Syria the geometric decoration is interspersed with some foliate elements, but this is largely in the form of acanthus leaves that, even when carved in curving rolls, are formal and lack the movement found in the comparative Sassanian leaf scrolls (Fig. 17). Taking these factors into consideration, once again it seems that the decorative inspiration at Tsilkani is likely to have been Sassanian in origin as close reading of the monument reveals any perceived Syrian influence to be superficial and unable to withstand close scrutiny.

However, as mentioned above, in Kartli where there is a plentiful supply of stone that can be easily dressed and carved, it is relatively simple to look for a relationship with neighbouring artistic traditions on the level of similarities in 
decorative scheme. In Kakheti to the east, where a relative lack of high-quality building materials means that a number of monuments there have been built with fieldstone and boulders salavaged from watercourses, then we are dealing with a vernacular that eschews decorative flourishes for practical reasons. When searching for relationships with other traditions in these circumstances it is necessary to leave questions of aesthetics behind and move on to the crucial relationship of the form and function of these monuments.

\section{Kakheti and the Enduring Question of the Triple Church Basilica}

One of the anomalies of early Georgian ecclesiastical architecture is the early appearance of 'Triple Church Basilicas'. For the uninitiated it is easy to assume that this term refers simply to a conventional basilica terminating in an apsed (or flat walled) sanctuary at the east end of the church and possessing north and south aisles that usually terminated in the small chambers that were commonly used for a variety of liturgical functions. This is a standard form of early Christian architecture and so does not appear particularly revolutionary at first sight; however if the reader takes a closer look at floorplans it soon becomes clear that something rather odd is happening. These 'Triple Basilicas' are designed so that there is either no communication between the central nave and the side aisles except via a narthex at the west end or, alternatively, they are only accessed via one door from the central nave into the auxiliary space created by the aisles, which almost appear to have been appended to the main structure as later appendages - even though it is clear that the entire monument was constructed at the same time. Another common element for this type of building, although this is not universal, is that the north and south aisles are semi-open to the elements due to the central sections of the north and south exterior walls being replaced by an arched arcade.

What is certain is that this is a peculiarly Georgian phenomenon and yet this fact seems not to have been recognised by specialists within the country. Time and again these monuments are referred to as being as of 'Syrian' origin and, when attempts are made to pin down this assertion there is frustratingly little indication as to where this belief originated. ${ }^{17}$ That this subgroup

17 The author has attempted to trace the origins of this assertion in conversation with a variety of art historians and archaeologists, in particular in discussion with art historian Dr. Nino Simonishvili and archaeologist Dr. Nodar Bakhtadze. Both confirmed that these basilicas were traditionally thought of as 'Syrian' and believed the assertion began with Chubinashvili although were unable to pinpoint a specific reference. Both were surprised 
of churches represented something unusual seems to have been recognised in the first half of the twentieth century when it was the subject of a monograph by Baltrušaitis ${ }^{18}$ but his work does little more than document where and when examples of 'cloisonné' churches (to use his terminology) have been discovered. He devoted the largest chapter of his slim volume on the phenomenon to Georgia, but whereas he raised a variety of pertinent questions, the work ultimately failed to offer any convincing explanations for why churches were constructed in this manner.

Another factor in the discussion is that of the dating of these churches. Until recently this architectural disposition has been largely associated with basilicas from the late fifth century onwards, with the latest examples appearing to have been built at the turn of the sixth and seventh centuries. This view was based upon the ages of the monuments still extant and did not take into account the possibility of earlier monuments being discovered in future archaeological excavations. However more recent information based on excavation suggests that some of the earliest churches built on Georgian territory followed this design and that therefore the evidence suggests that we are dealing with a vernacular ecclesiastical variant that predates the standardisation of church building and the liturgy in Kartli.

Recent discoveries have led to a re-evaluation of older excavation reports and the data from older campaigns can now be seen to support newer findings demonstrating that these 'triple' basilicas were being built as early as the second half of the fourth century. For example two churches built in this way were excavated in Areshi, east of Kvareli in Kakheti in the late 1970s and early 1980s under the direction of Levan Chilashvili ${ }^{19}$ but were not recorded as being 'triple' basilicas because their dating did not accord with the widely received interpretation published by Chubinashvili that such basilicas did not appear until a later period. ${ }^{20}$ However the more recent discoveries of much larger triple basil-

to learn that no such monument is known from Syria-in either Syria or the part of contemporary Syria that lies east of the Euphrates in antique Assyria/Mesopotamia.

Baltrušaitis, Jurgis, L'Église Cloisonné en Orient et en Occident, Les Éditions D' Art et D' Histoire; Paris, 1941.

19 See Chilashvili, L., Kiknadze, G., Apkhazava, N. \& Bakhtadze, N., 'Areshis nakalakaris gatkhrebi (1978-1979 tsts.)', Sakartvelos sakhelmtsipo muzeumis arkeologiuri ekspeditsiebi 7 (1980), pp. 64-78, Chilashvili, L., Kiknadze, G., Apkhazava, N., Bakhtadze, N. \& Gotsadze, K., 'Areshis ekspeditsiis shedegebi', Sakartvelos sakhelmtsipo muzeumis arkeologiuri ekspeditsiebi 8 (1986), pp. 92-105.

Prof. Nodar Bakhtadze, pers. comm. 
icas at Chabukauri and Dolochopi in the territory of Nekresi and their dating to the late fourth and early fifth centuries suggest that the Areshi discoveries were in fact typical for the Kakhetian vernacular church architecture of the earliest Christian era rather than being an anomaly.

This issue is particularly sensitive because Nekresi has traditionally been regarded as the site of the earliest church in Georgia still extant. The problem is that the monument in question is not one of the basilicas being discussed. Rather it is a curious, misshapen monument that has openings in all of the cardinal directions and no obvious space set aside for the processes of religious ritual (Fig. 1). It is immediately clear that this small and irregular building is in fact a prototype mortuary chapel—a fact that has been confirmed by archaeological exploration in the chamber beneath the main floor of this 'basilica.' The excavations have revealed the cavities in which the faithful would pour oil, in order for it to pass over the bones of the 'martyrs' and be sanctified for use by the faithful, as well as a common grave with bones believed to have belonged to a number of the earliest monks at the site. ${ }^{21}$ Because this monument was declared a prototype basilica by Chubinashvili there has been a certain reluctance to move on from the former fourth century date attributed to the building and to process the more recent research that has demonstrated its role as a sixth century shrine visited by pilgrims who wished to share in the blessings of the holy men buried at the site. ${ }^{22}$

Unlike in other regions where dating has been based purely on an architectural typology, the basilicas of Chabukauri and Dolochopi (both the upper and lower churches on the two sites) have been dated from an analysis of the stratified ceramic and numismatic deposits found during the excavation. In the case of Dolochopi the dating of the lower church as fourth century has been confirmed by $\mathrm{C} 14$ testing of carbon deposits found at the site. ${ }^{23}$ These results demonstrate on the one hand that Christianity had spread throughout Kartli and Kakheti remarkably swiftly and that large, sophisticated places of Christian

\footnotetext{
$21 \quad$ As above in note 21.

22 In fact the picture appears to be even more complex as the mortuary remains appear to have been of both clerics and wealthy lay people of both sexes, but the limitations imposed on the excavators by the monastic custodians of the site mean that the implications of this information have yet to be fully explored. At the time of writing future permission to continue archaeological exploration at this site seems unlikely.

23 The tests have been calibrated at $387 \mathrm{CE}$ with $93.2 \%$ probability (Laboratory Code suERC70629 ) and between $388 \mathrm{CE}$ with $68.2 \%$ and $401 \mathrm{CE}$ with $95.4 \%$ probability, but this second sample appears mixed with earlier material (Laboratory Code suERC-76888).
} 
worship were already being constructed before the end of the fourth century. On the other hand the unusual construction of these buildings suggests that there was a vernacular current of regional architecture that was adapting the conventional basilica form found across the Romano-Byzantine empire into a distinctly local idiom and that this idiom spread across from Kakheti into Kvemo Kartli, where we find later examples of this form at Kvemo Bolnisi and Bolnisi Sioni. If we can for the moment leave aside the possible liturgical reasons for this design, which is an area requiring a wholly new study, then what we can draw from the monuments in the vicinity of Nekresi and in Areshi is that where there has been archaeological exploration of early Christian sites in Kakheti thus far they have yielded surprisingly early evidence of constructions following the 'triple' basilica form. At Areshi these were relatively modest in size but at both Chabukauri and Dolochopi, where there is evidence that the churches were built at the heart of substantial contemporary settlements, these finished monuments were exceptionally large reaching $34 \times 15$ metres and $36 \times 18.5$ metres respectively.

By choosing to build early churches in the form of basilicas the people of Kartli and Kakheti were following a practice that was widespread across the early Christian world and it is not possible to argue for a distinct Syrian (or otherwise) influence on these monuments as the basilica form was so ubiquitious a feature of early Christian architecture. Having said that, this Kakhetian form did possess a key variation on the normal design by cutting off the north and south aisles from the central nave or, in some cases becoming a five nave basilica by having a conventional central nave with arcades and north and south aisles, and then having additional apsed aisles outside the main body of the church that replicated the 'triple' basilica form - this 'five naved' variant is best seen today at Bolnisi Sioni. A lack of comprehensive excavation in Kvemo Kartli means that we cannot yet know whether this form of architecture sprang up in the region at the same time that we find it in Kakheti, with buildings being constructed to this pattern in the second half of the fourth century, or whether the form spread to the region from the east as travellers or artisans transplanted the form of Kakhetian churches to the southwest. What is becoming increasingly clear is that we can trace a line of progression from the fourth and fifth century early monuments of this type at Areshi, Chabukauri and Dolochopi through to the sixth to seventh century refined forms of these churches in the slightly smaller basilicas conforming to the same pattern at places such as Nekresi (Fig. 18) and south across the Alazani valley at Zegaani (Fig. 19) and Dzveli Shuamta. The factor to be reconciled remains the two fifth century monuments fitting this pattern at Bolnisi and Kvemo Bolnisi. 


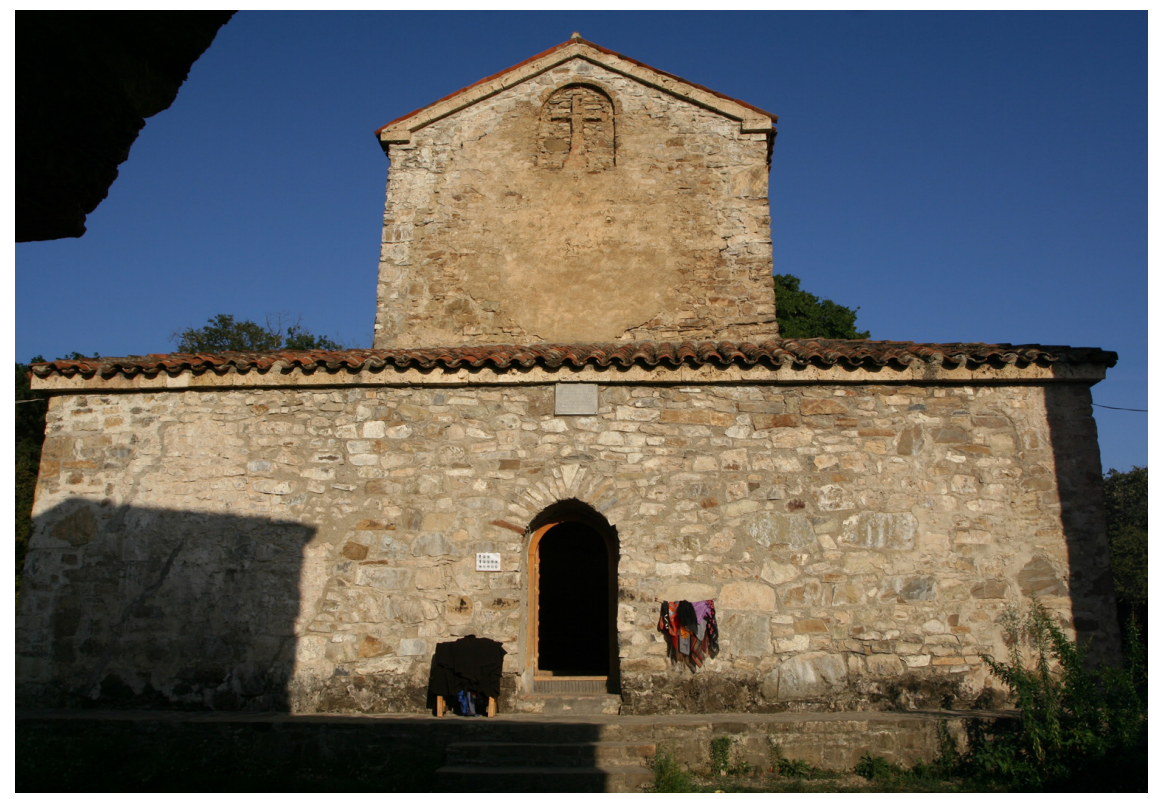

FIGURE 18 West façade of the sixth-seventh century basilica at Nekresi

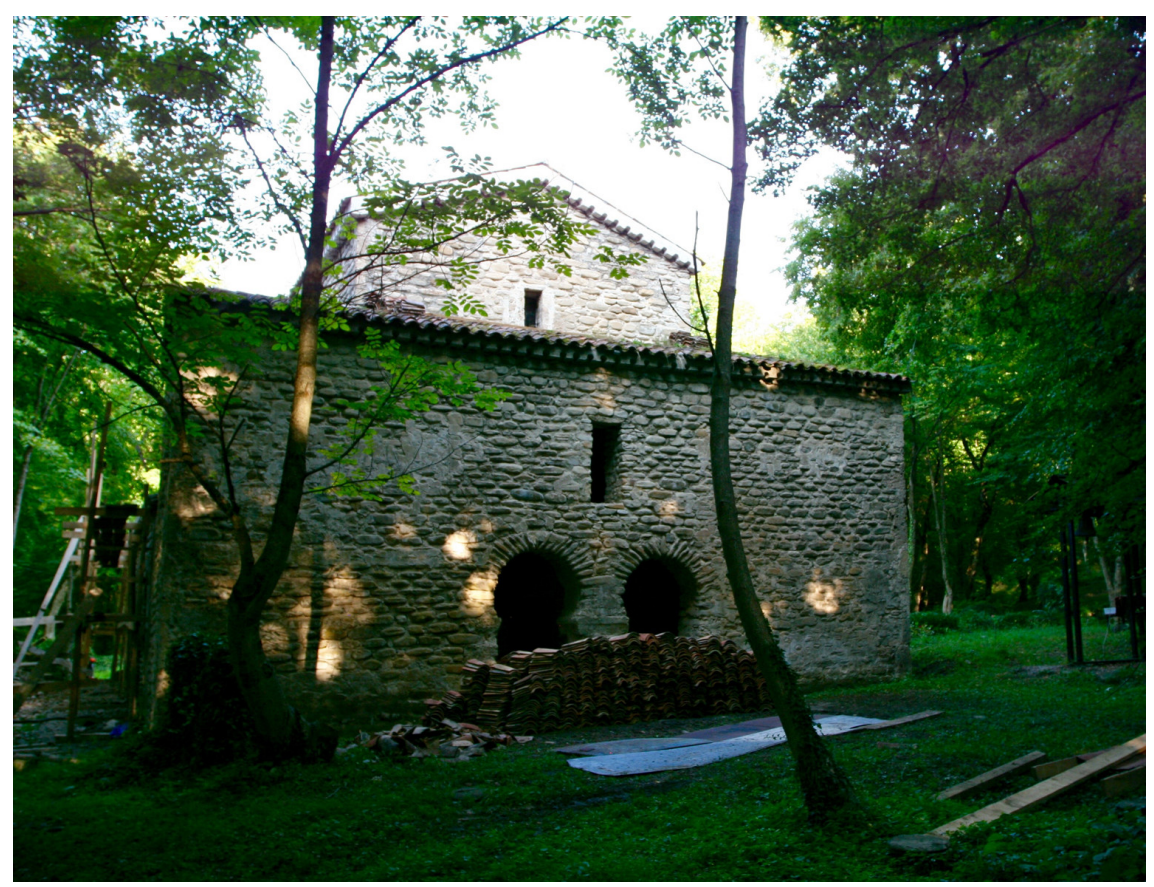

FIGURE 19 West façade of Zegaani basilica 
If we cannot entirely reconstruct the entire evolution of the basilica in Kakheti and Kartli, we can at least acknowledge that none of these monuments has yielded any evidence of contact with Syria unless we place a strong significance in the ubiquitious presence of Syrian glass. The Kakhetian sites discovered an overwhelming preponderance of Persian-minted numismatic evidence and any small finds that were not Persian or produced locally fall into the category of generically produced Byzantine wares. Nothing found at any of these locations has pointed us in the direction of a close link with Syria, but all have provided copious evidence suggesting a relationship with the south and east with the evidence from Kvemo Kartli providing architectonic and epigraphic evidence of links with Persia and those in Kakheti showing the relationship in the number of Persian objects, and in particular Persian coins, being excavated in the vicinity of these churches.

It has been argued that the form of the 'triple basilica' itself can be linked to this Persian influence with Kipiani positing that the temple complex found on the plain beneath Nekresi in a location that fell between the two sites of Chabukauri and Dolochopi was a forerunner of this form of Christian architecture.$^{24}$ His argument hinges on the identification of the temple complex as being a Manichaean monastery that acted as an inspiration for a new Christian form of architecture. Although this issue lies outside the parameters of the present study, it is interesting to note that the question of Manichaean influences on eastern Georgia is increasingly gaining the attention of scholars with Mgaloblishvili and Rapp also arguing that the faith gained popularity in late antique Kartli. ${ }^{25}$ How far early Christian monuments in Kartli and Kakheti were or were not influenced by other faith traditions, in the simplest terms the first places of Christian worship in Georgia appear to have followed a widespread pattern found across the early Christian world in initially adopting the basilica form. Therefore it seems that the changes undertaken by Georgian ecclesiastical architecture towards the type of building we associate with Georgian churches today, occurred in the later fifth century onwards as there was a move towards smaller, centrally planned monuments and here the picture becomes more complex as we search for the origins of this change.

\footnotetext{
24 Kipiani, Guram, 'Nekresis “didi kvadrati”', Kadmosi 1 (2009), pp. 214-251.

25 Mgaloblishvili, Tamila \& Rapp, Stephen H. Jr, 'Manichaeism in Late Antique Georgia?', in Van den Berg, Jacob Albert (ed.), In Search of Truth: Manichaica, Augustiniana and Varia Gnostica, Brill; Leiden and Boston, 2011, pp. 263-29o.
} 


\section{Rome, Constantinople, Syria, Armenia and Georgia: The Spread and Function of Centrally Planned Churches}

Much has been written on the evolution of centrally planned churches and the question of their form and function, given that they do not so obviously lend themselves to the practice of the Eucharistic liturgy that soon became an important function of most Christian places of worship in such a straightforward manner as the simpler basilica form. From the start centrally planned monuments in Christian contexts appear to have been associated with funerary or memorial functions, as with Santa Constanza in Rome, the Martyrium of St. Babylas on the outskirts of Antioch at Qausiyeh and, the most famous of them all, the Anastasis Rotunda at the Church of the Holy Sepulchre in Jerusalem. However it is clear that the boundaries between different forms of ecclesiastical design were permeable and by the fifth and sixth centuries it was increasingly common to find centrally planned churches that were not being constructed purely for commemorative purposes. Aside from the church of ss. Sergius and Bacchus in Constantinople, that has been linked to monophysite communities in the city, ${ }^{26}$ this is a form of architecture that in Syria at least came to be associated with those who upheld the rulings of the Council of Chalcedon and therefore it remains something of an anomaly that this centralised plan should find such favour with the resolutely anti-Chalcedonian Armenians and in Georgia at a period when, in the east at least, the Church was not believed to be in union with Constantinople.

The argument that links doctrinal identity with the usage of centrallyplanned monuments in Syria follows the fact that thus far all such monuments have been found in the western and central regions of the country in places such as Bosra, where they are linked to the local Chalcedonian hierarchy. In the heartlands of the Syrian Orthodox Church, which rejected the Council of Chalcedon, centrally planned churches were more commonly used as baptisteries or mortuary chapels as with the Church of St. Jacob in Nisibis (modern Nusaybin) or the dome of the Egyptians and the dome of the departed at Dayr Mar Gabriel in the Tur 'Abdin region of southeastern Turkey. ${ }^{27}$ However the Syrian Orthodox did not adopt centrally planned churches for other types of

26 See Bardill, Jonathan, 'The Church of Sts. Sergius and Bacchus in Constantinople and the Monophysite Refugees', Dumbarton Oaks Papers 54 (2000), pp. 1-11 and Croke, Brian, 'Justinian, Theodora, and the Church of Saints Sergius and Bacchus', Dumbarton Oaks Papers 6 o (2006), pp. 25-63.

27 Keser-Kayaalp, Elif, 'The Beth Qadishe in the Late Antique Monasteries of Northern Mesopotamia (South-Eastern Turkey)', Parole de l'Orient 35 (2010), pp. 325-348. 
ecclesiastical usage - their monastic, cathedral and ordinary parish churches all conformed to the basilica form even if in certain regions they used transverse naves rather than the usual orientation of a longitudinal east-west axis. ${ }^{28}$ With this borne in mind we must question how and why there was a movement towards centrally planned monuments in the Transcaucasus when we know that Armenia has always been overwhelmingly anti-Chalcedonian and, until the early seventh century, the majority of Kartli and Kakheti was also believed to have rejected the doctrinal position of Constantinople.

This association of building types with doctrinal identity and the fact that Armenia appeared to have broken with these conventions was highlighted by Kleinbauer in 1972 when he tried to reconcile the centrally planned church at Zvart'nots with the anti-Chalcedonian stance of the Armenian Church:

Sebeos ... and John the katholikos ... report that Nerses III harbored secret Chalcedonian sympathies. Why then did he select a prototype from Syria which was Monophysite? First of all, it seems that all the Syrian tetraconchs were founded by members of the Orthodox faith, and some of them remained in Orthodox hands until the 7 th century. ${ }^{29}$

In other words, centrally planned churches in Syria were inextricably linked with 'Orthodox' (i.e. Chalcedonian) clergy and so a choice of this kind of building was a sign of Chalcedonian sympathies. Some years later Maranci argued that it was in fact precisely because of the Chalcedonian doctrinal resonance that Nerses selected this form of architecture:

28 This is a phenomenon recorded by Gertrude Bell at Dayr Mar Gabriel and the the nearby church of Mar Yakub at Salah, see Bell, Gertrude Lowthian (with intoduction and notes by Mango, Marlia Mundell), The Churches and Monasteries of the Tur Abdin, The Pindar Press; London, 1982, pp. 6-13 but is also encountered in Syria, notably at the church of the Entrance of the Theotokos in the Temple in Hama. It must be noted here that the original denominational identity of the church in Hama is unknown, whereas the Tur 'Abdin monuments mentioned above are overwhelmingly identified with the Syrian Orthodox tradition. This relationship between the two regions is explored in Fourdrin, Jean-Pascal, 'Les églises à nef transversal d' Apamène et du Țûr 'Abdîn', Syria 62:3/4 (1985), pp. 319-335. Fourdrin takes the view that transversal naves in the Tur 'Abdin are a factor that enables us to tell Syrian Orthodox monasteries in Byzantine territory from Assyrian (Church of the East) monasteries in Persian territory but his argument is, to this reader at least, too speculative to be given serious consideration.

29 p. 262, note 71, Kleinbauer, W. Eugene, 'Zvart'nots and the Origins of Christian Architecture in Armenia', The Art Bulletin 54:3 (1972), pp. 245-262. 
Kleinbauer suggested that the adoption of the aisled tetraconch reflects a desire to foster relations with Syrian Monophysites. The opposite, I believe, may be argued. As Kleinbauer himself observed, all the Syrian aisled tetraconchs were Orthodox foundations, and they remained in Orthodox hands, it seems, through the seventh century ...

... It is significant that the structures most like Zuart'noc' stand in important centers of Orthodoxy. Given Nersēs' Chalcedonian inclinations, it seems likely that he adopted the architectural form for its associations with Byzantine Christianity rather than because of its Syrian and Mesopotamian connections. ${ }^{30}$

One problem raised by Kleinbauer's work is that despite mentioning Syrian and Mesopotamian exemplars of this form of church that he called 'aisled tetraconchs' only one of his examples was actually in Mesopotamia, that of the Church of the Virgin in Amida (modern Diyarbakir in Turkey) ${ }^{31}$ and therefore the overwhelming majority of his examples fall in Syria. It is not a form of ecclesiastical architecture that features widely in Mesopotamian churches and therefore can be viewed as being more a product of the Romano-Byzantine than the Sassanian world, despite the fact that centrally planned buildings were not unknown to the Sassanians.

So if we take all these factors into account we are left with two clear patterns; centrally planned churches entered from the west and south. They appeared in Syria and Asia Minor as early as the fifth century, but do not appear to have become widespread in Armenia and in Georgia as the so-called 'Jvari-type' until the end of the sixth or the beginning of the seventh century. What we also know is that a second current of domed architecture was also entering from the east,

30 p. 116, Maranci, Christina, 'Byzantium through Armenian Eyes: Cultural Appropriation and the Church of Zuart' Noc', Gesta 40:2 (2001), pp. 105-124.

31 It should also be noted that of his 'Armenian' examples of this form, only Zvart'nots falls firmly within Armenian territory. Ishkani and Bana are in the region of contemporary Turkey that was known to the Armenians as Tayk and the Georgians as Tao-Klarjeti. Both monuments are today claimed as Georgian cultural patrimony, with Georgian agencies working on the monuments with the agreement of the Turkish state. This is not the place to enter into the complex debate as to what constitutes an Armenian monument and what constitutes a Georgian one, but suffice it to say that the situation is more complex than simply attributing the monuments to an Armenian origin. With the church at Lekit, whilst it lies in contemporary Azerbaijan and is not subject to a current claim in the same way as the Georgians argue that the monuments of Tao-Klarjeti are theirs, nevertheless it was built by the Caucasian Albanians of whom relatively little is now known and therefore once again we must be wary of attributing to it a wholly Armenian origin. 
specifically from Persia, where it was not associated with Christian architecture but nevertheless does seem to have played some part in the evolution of domed churches.

Within Georgian art historical discourse there has been only limited discussion of these issues due to the fact that Chubinashvili was clear that he felt that the origins of ecclesiastical domed architecture were firmly rooted in vernacular Georgian domestic architecture. Specifically he viewed the dome as a natural progression of the traditional darbazi house where a pyramidal roof with a central aperture was constructed by layers of overlapping wooden beams to build up a conical structure that terminated with a circular opening to allow smoke to exit from the hearth located directly beneath it. ${ }^{32}$ Given the presence of this traditional form of architecture still in use at the time of his writing, ${ }^{33}$ Chubinashvili argued that this native domestic form was the natural origin of the centrally planned church. Even accepting the limitations placed on Soviet era scholars, this was an extraordinarily nationalistic argument that, perhaps deliberately, failed to engage with the phenomenon even in neighbouring Armenia let alone with the wider picture across Asia Minor and the Levant. What this view also disregarded was the fact that in the fifth century domed churches were emerging across Asia Minor and Syria in the west and south and, returning for a moment to the issue of non-Christian influences on Georgian Christian architecture, in the east the Sassanians used domes for a variety of structures including in a religious setting by employing them on the central chambers of Zoroastrian temples. ${ }^{34}$ We can be sure that this phenomenon was familiar in Kartli as a fire temple (ateshgah) believed to date from the fifth century is still extant in the old city of Tbilisi in the vicinity of the Zemo Betlemi (Upper Bethlehem) church, which is ascribed similarly ancient origins although the church has been rebuilt so many times that the picture of its original foundation is now difficult to recreate with any certainty.

32 p. 192, Chubinashvili, Giorgi N., 'On the initial forms of Christian Churches' in Mgaloblishvili, Tamila (ed.), Ancient Christianity in the Caucasus, Curzon; Richmond, 1998, pp. $185^{-195}$.

33 Today very few darbazi structures are still extant. In Tbilisi one survives as part of an hotel in the Metekhi quarter of the city but the easiest way to see a darbazi houses is to visit the examples that have been reconstructed on the territory of the Georgian National Museum Giorgi Chitaia Open Air Museum of Ethnography which stands on a mountainside above the Vake district of Tbilisi.

34 pp. 99 ff., Ashkan, Maryam \& Ahmad, Yahaya, 'Persian Domes: History, Morphology and Typology', Archnet-IJAR: International Journal of Architectural Research 3:3 (2009), pp. 98115 . 


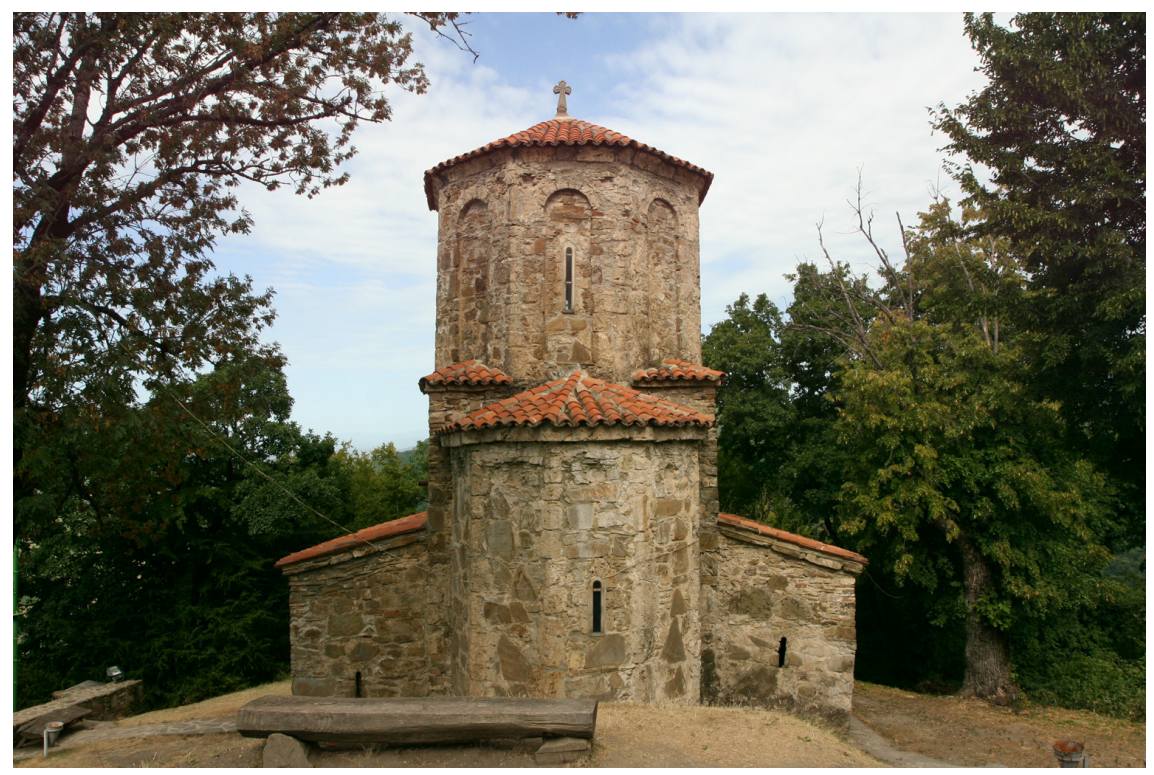

FIGURE 20 East façade of centrally-planned church at Nekresi

This Persian form of domed architecture relied on the use of squinches rather than the more sophisticated, though similar looking, pendentives to support a circular dome on a square base and the Persian influence is visible in the two seventh century centrally planned churches at Dzveli Shuamta in Kakheti, as well as the eighth to ninth century example at the monastic complex of Nekresi (Fig. 2O). Therefore it seems clear that Kartli and Kakheti stood at the confluence of two distinct traditions of domed architecture and, perhaps unsurprisingly, absorbed elements of both into the local ecclesiastical tradition. In reality this meant that, obviously, the domed monuments of the Jvari type and the domed basilicas found in Kartli at Tsromi (Fig. 21) and in Armenia at Mren, Bagavan (both sites now in Turkey) and the church of Gayane at Echmiadzin (Fig. 22) took inspiration from movements in Syria, where centrally planned churches evolved in the fifth century. Later the dome reached its apogee with Justinian's great church of Hagia Sophia in Constantinople and it is clear that all of these movements fed into the spread of domed architecture that flourished at the turn of the sixth and seventh centuries in both Kartli and Armenia.

On the other hand there are other domed buildings that look decidedly experimental by comparison and in these cases it is perhaps reasonable to suggest that artisans who had seen the less developed Sassanian form of dome were attempting to utilise this innovation in a more Christian idiom. It is into 


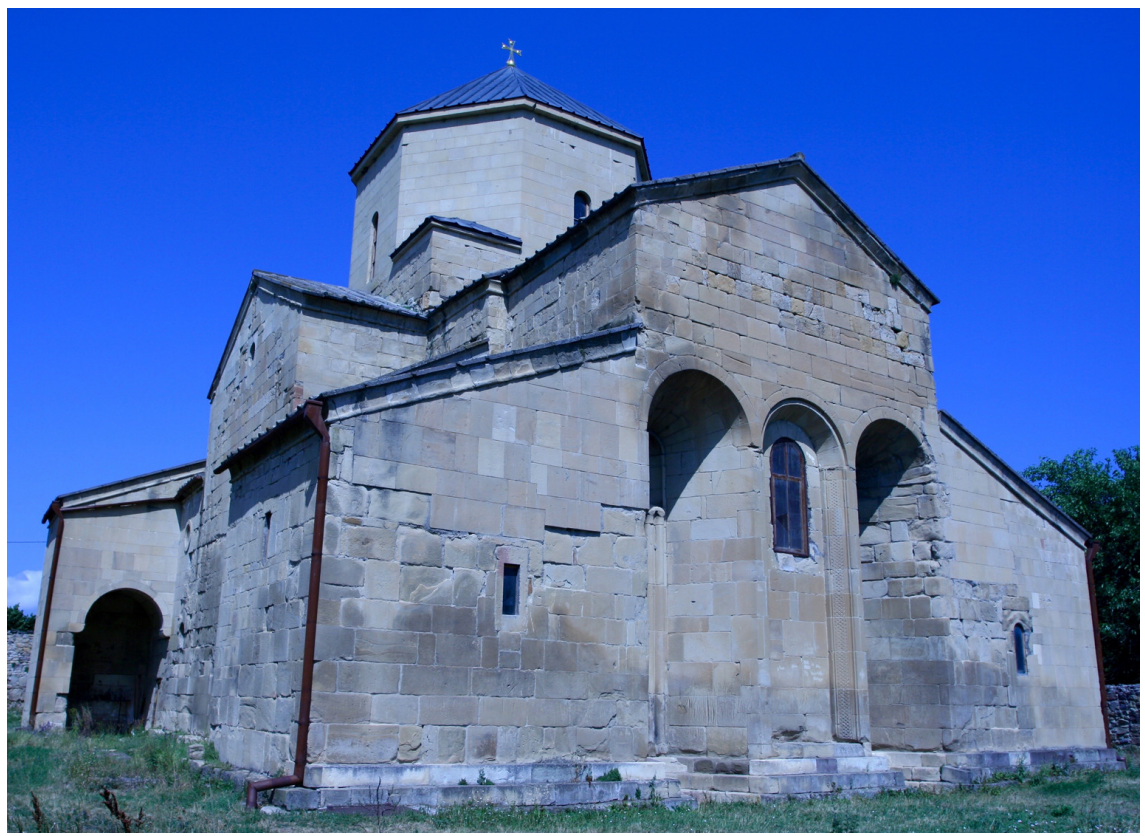

FIGURE 21 Tsromi

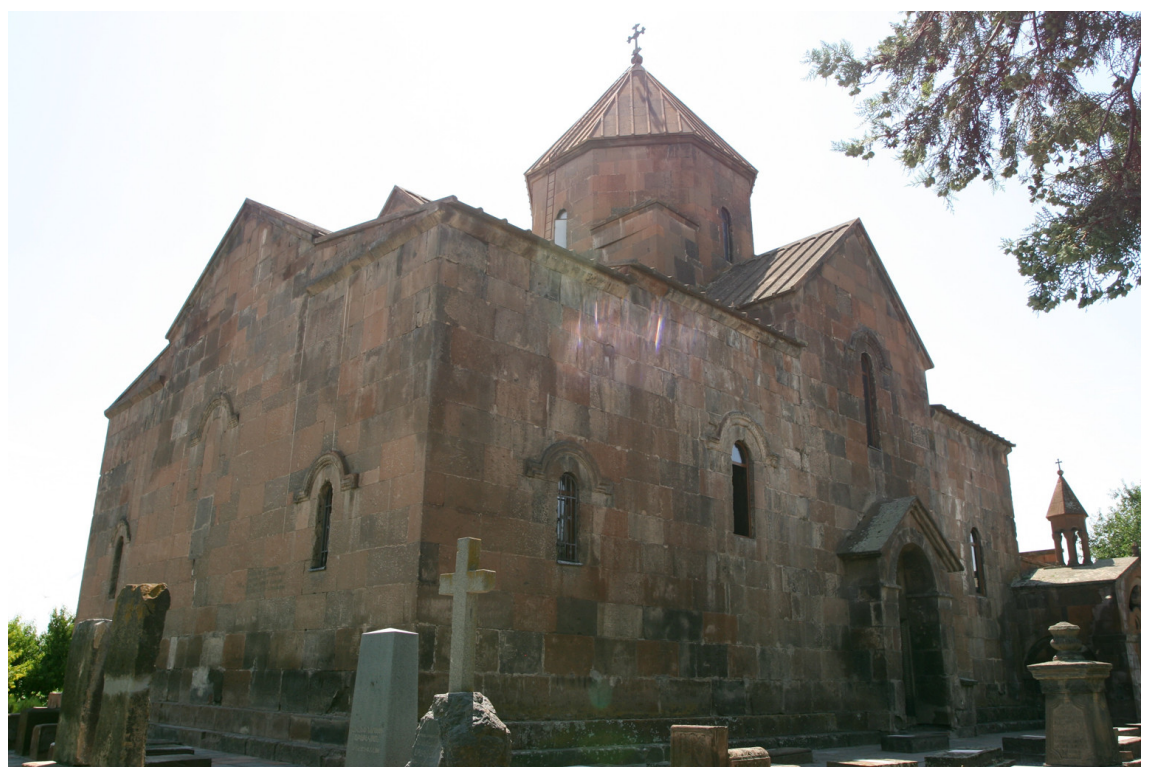

FIGURE 22 St. Gayane, Echmiadzin 


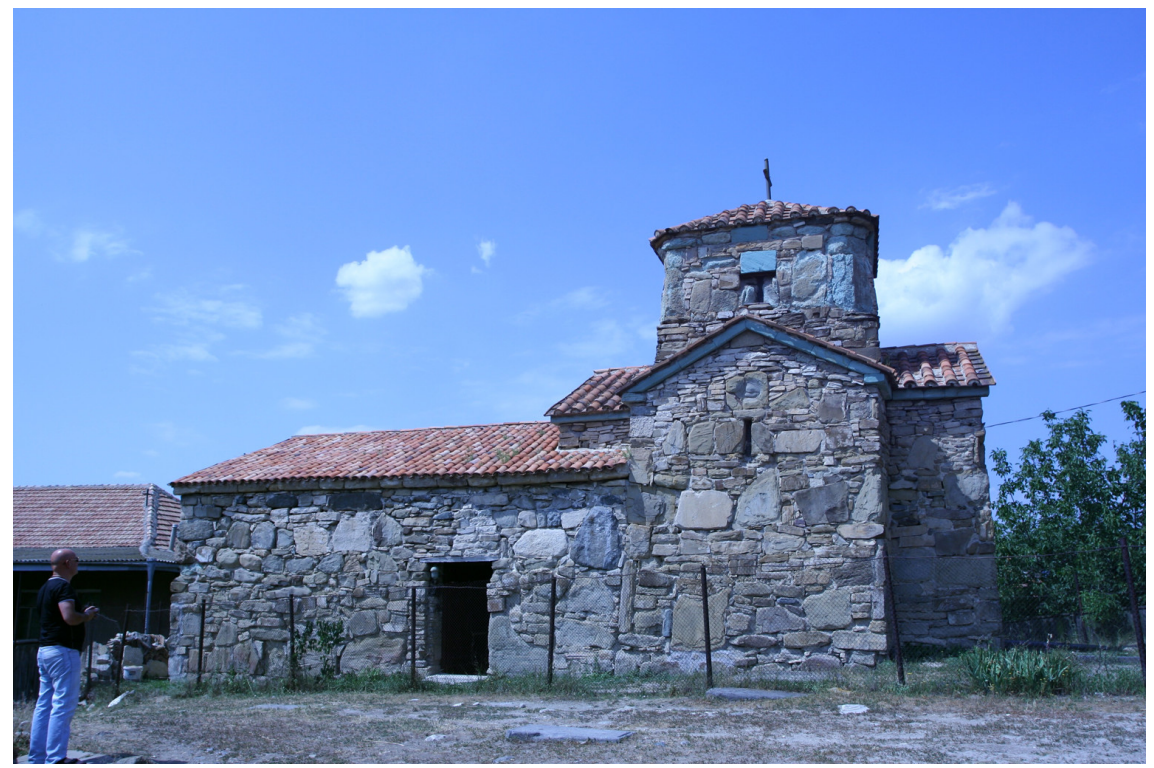

FIGURE 23 Idleti, southern façade showing extended narthex

this category that one may place the small church at Idleti in Shida Kartli, where the central dome is encased within a square exterior suggesting that the builders of this church were unfamilar with sophisticated geometrical planning and therefore the elegant polygonal drum that became widespread from the end of the sixth century proved to be beyond their capabilities (Fig. 23). In short, when it comes to domed architecture it seems apparent that whereas one current came into Kartli and Kakheti from the Sassanian empire in the east, the influence that proved most longlasting was that coming from the south where Syrian centrally planned and domed monuments appear to have been a formative influence on the Christian architecture of the Transcaucasus as a whole.

This raises questions as to the movements of artisans and whether or not itinerant craftspeople from elsewhere moved across Syria, Asia Minor and the Transcaucasus in search of work. At the time of writing little consideration has yet been given to this issue, not least because addressing the question of the Armenian artisans who obviously worked on the seventh century Jvari type church of Ateni Sioni in Shida Kartli is politically contentious in contemporary Georgia. The Ateni Sioni Armenian inscriptions are believed to refer to the tenth century restoration of the monument rather than the seventh century construction of the church which Rapp takes as an indication of Armenian Chalcedonian presence in medieval Kartli. He suggests that: 
In any event, it is evident that at least in ninth- and tenth-century K'art'li, Chalcedonian Armenians were accepted as de facto members of the Orthodox, Chalcedonian K'art'velian Church. This is absolutely possible, for this was not a nationalistic period. Religious affiliation was regarded as the key to community in this instance. ${ }^{35}$

Whether or not this argument is correct in the later period being discussed by Rapp in the period under discussion, which is the fifth to the early seventh century, it is unclear how far artisans would have been directly affected by the aftermath of the doctrinal upheavals of the Councils of Ephesus and Chalcedon and whether pronouncements of kings and bishops had a significant effect on the attitude of common workmen. Certainly the evidence suggests that it was not until the mid sixth century onwards that positions began to crystallise outside the monastic world ${ }^{36}$ and the similarity between groups of monuments constructed in the early seventh century on both sides of the contemporary frontier between Georgia and Armenia would suggest that the doctrinal barrier was no impediment to talented craftsmen. Certainly the similarities between the domed basilica of Tsromi in Shida Kartli built between 626 and $634^{37}$ and the churches of Mren, Bagavan and Gayane which are mentioned above and all belonged to the Armenian Orthodox tradition, would argue for the movement of artisans backwards and forwards across the fluid territorial boundaries of the time in search of work. Few patrons were wealthy enough to keep master builders and masons in work for an entire lifetime and therefore such workers would have been accustomed to travel in search of new commissions. It is perhaps projecting hindsight onto the situation to suggest that the people of the time would all have held fixed doctrinal viewpoints that could have affected their choice of work - as is the case today, no doubt such questions would have been significant to some artisans whereas others were likely to have been primarily motivated by the need to secure regular payment.

35 p. 648, Rapp, Stephen Harold, Jr. "Imagining History at the Crossroads: Persia, Byzantium, and the Architects of the Written Georgian Past.” Order No. 9722070, University of Michigan, 1997, https://search.proquest.com/docview/304378571?accountid=10792 (accessed April 12, 2017).

36 See for example Menze, Volker L., Justinian and the Making of the Syrian Orthodox Church, Oxford University Press; Oxford, 2008 for the argument that even a century after Chalcedon there was still a hope that the rift could be healed through mediation—although the attempt ended in failure and a permanent division resulted. 
This recurring question of doctrinal identity and how it could have shaped the physical form of church buildings is perhaps an opportune moment to move away from this discussion of the forms of ecclesiastical monuments and to consider the question of their function. For this we must examine the ritual usage of churches in both Syria and Kartli and it is to that we shall turn in the next chapter. 